\title{
Gambaran hematologi rutin dan hubungannya dengan rerata gula darah pada pasien diabetes melitus tipe 2 di Poliklinik Endokrin RSUP Prof. Dr. R. D. Kandou Manado
}

\author{
${ }^{1}$ Gita C. Kekenusa \\ ${ }^{2}$ Karel Pandelaki \\ ${ }^{2}$ Harlinda Haroen
}

\author{
${ }^{1}$ Kandidat Skripsi Fakultas Kedokteran Universitas Sam Ratulangi Manado \\ ${ }^{2}$ Bagian Ilmu Penyakit Dalam Fakultas KedokteranUniversitas Sam Ratulangi Maando \\ Email: gitakenn@yahoo.com
}

\begin{abstract}
Diabetes mellitus (DM) is a group of metabolic diseases characterized by hyperglycemia due to a defect in insulin action, insulin secretion by pancreatic beta cells or both. In patients with type 2 diabetes (T2DM), trombopoiesis acceleration and increased turnover and increased hematocrit occur resulting in impaired blood flow velocity. This increased blood viscosity causes vasoconstriction due to thickening of blood vessel walls.This study was aimed to obtain the profile of hematology and its correlation with average blood glucose in type $2 \mathrm{DM}$ patients. This was a descriptive analytical study using patients' medical record in the Endocrine Clinic of Prof. Dr. R. D. Kandou Hospital Manado from August to October 2016. The results of Spearman's correlation test were as follows: correlation between average blood glucose and hemoglobin concentration with $\mathrm{r}=0.083$ and $\mathrm{p}=0.272$; correlation between average blood glucose and levels of hematocrit with $r=0.123$ and $p=0.184$; correlation between the average glucose blood and levels of erythrocyte with $r=0.121$ and $p=0.187$; correlation between average blood glucose and platelet with $r=0.052$ and $p=0.353$; and correlation between average blood glucose and levels of leukocytes with $r=0.247$ and $p=0.033$. Conclusion: Among type 2 DM patients, there were no significant correlations between average blood glucose level and hemoglobin, hematocrit, and erythrocyte levels, as well as platelet levels. However, there was a significant correlation between average blood glucose and leukocyte level.
\end{abstract}

Keywords: T2 DM, average blood glucose, hemoglobin, hematocrit, platelets

\begin{abstract}
Abstrak: Diabetes Melitus (DM) merupakan suatu kelompok penyakit metabolik yang ditandai oleh hiperglikemia akibat defek pada kerja insulin, sekresi insulin oleh sel beta pancreas, atau keduanya. Pada pasien DM tipe 2 (DMT2) terjadi percepatan trombopoiesis serta peningkatan pergantian trombosit dan hematokrit yang dapat berakibat terhadap kecepatan aliran darah. Viskositas darah yang meningkat dapat menyebabkan terjadinya vasokonstriksi akibat penebalan dinding pembuluh darah. Penelitian ini bertujuan untuk mengetahui gambaran hematologi dan hubungannya dengan rerata gula darah pada pasien DM tipe 2. Jenis penelitian ini deskriptif analitik dengan menggunakan data rekam medik pasien di Poliklinik Endokrin Bagian/SMF Ilmu Penyakit Dalam RSUP Prof. Dr. R. D. Kandou Manado periode Agustus-Oktober 2016. Hasil uji korelasi Spearman memperlihatkan nilai hubungan antara rerata gula darah dan kadar hemoglobin $\mathrm{r}=0,083$ dan $\mathrm{p}=0,272$; nilai hubungan antara rata-rata gula darah dan kadar hematocrit $r=0,123$ dan $p=0,184$; nilai hubungan antara rata-rata gula darah dan kadar eritrosit $\mathrm{r}=0,121$ dan $\mathrm{p}=0,187$; nilai hubungan antara rata-rata gula darah dan trombosit $\mathrm{r}=0,052$ dan $\mathrm{p}$ $=0,353$, serta nilai hubungan antara rata-rata gula darah dan kadar leukosit $r=0,247$ dan $p=$ 0,033. Simpulan: Pada pasien DMT 2 tidak dijumpai hubungan bermakna antara rerata gula darah dengan kadar hemoglobin, kadar hematokrit, kadar eritrosit, dan kadar trombosit namun terdapat hubungan bermakna antara rerata gula darah dan leukosit.
\end{abstract}

Kata kunci: DMT2, rerata gula darah, hemoglobin, hematokrit, trombosit 
Diabetes Melitus (DM) merupakan suatu kelompok penyakit metabolik yang ditandai oleh hiperglikemia akibat defek pada kerja insulin (resistensi insulin) di hati (peningkatan produksi glukosa hepatik) dan di jaringan perifer (otot dan lemak), sekresi insulin oleh sel beta pankreas atau keduanya. ${ }^{1}$

International Diabetes Federation (IDF) menyebutkan bahwa prevalensi DM di dunia mencapai $1,9 \%$ dan menjadikan DM sebagai penyebab kematian urutan ke tujuh di dunia. Pada tahun 2012 angka kejadian DM di dunia mencapai 371 juta jiwa dimana proporsi kejadian DM tipe 2 mencapai $95 \%$ dari jumlah penderita DM di dunia. ${ }^{2}$

Dari berbagai penelitian epidemiologis di Indonesia didapatkan prevalensi DM sebesar 1,5-2,3 \% pada penduduk usia lebih dari 15 tahun, bahkan pada suatu penelitian epidemiologis di Manado didapatkan prevalensi DM 6,1\%. Penelitian yang dilakukan di Jakarta, Surabaya, Makasar dan kota-kota lain di Indonesia membuktikan adanya kenaikan prevalensi dari tahun ketahun. Berdasarkan pola pertambahan penduduk, diperkirakan pada tahun 2020 nanti akan ada sejumlah 178 juta penduduk berusia diatas 20 tahun dan dengan asumsi prevalensi DM sebesar $4 \%$ akan didapatkan 7 juta pasien DM. Pada laki-laki prevalensinya $2,0 \%$ dan perempuan $2,3 \%$. Dari faktor usia, prevalensi DM tertinggi pada usia 55-64 tahun dengan 5,5\%. ${ }^{3}$ Jumlah pasien yang berkunjung di Poliklinik Endokrin dan Metabolik RSUP Prof. Dr. dr, R. D. Kandou Manado periode Mei-Oktober 2011 adalah sebanyak 3.998 pasien. Dari jumlah 3.998 pasien tersebut ditemukan pasien DM tipe 2 baru sebanyak 138 pasien yang terdiri dari 60 laki-laki (43\%) dan 78 perempuan $(57 \%){ }^{4}$

Diperkirakan bahwa pada tahun 2030 prevalensi DM di Indonesia mencapai 21,3 juta orang (Diabetes Care, 2004). Sedangkan Riskesdas tahun 2007, diperoleh bahwa proporsi penyebab kematian DM pada kelompok usia 45-54 tahun di daerah perkotaan menduduki ranking ke-2 yaitu $14,7 \%$ dan daerah pedesaan, DM menduduki ranking ke-6 yaitu 5,8\%. ${ }^{5}$ Kematian yang tinggi disebabkan oleh komplikasi diabetes yang tidak terkontrol.

Pada pasien DM tipe 2 terjadi percepatan trombopoiesis dan peningkatan pergantian trombosit atau yang biasa disebut platelet turnover ${ }^{7-9}$ Peningkatan dua kali lipat pergantian trombosit terjadi karena waktu kelangsungan hidup trombosit menurun dan peningkatan masuknya trombosit-trombosit baru ke dalam sirkulasi. ${ }^{10}$ Peningkatan hematokrit dapat mengakibatkan kecepatan aliran darah terganggu. Hal ini berkaitan dengan viskositas darah yang meningkat menyebabkan terjadinya vasokonstriksi akibat penebalan membran pembuluh darah. $^{11,12}$

Penelitian ini bertujuan untuk mengetahui gambaran hematologi dan hubungannya dengan rata-rata gula darah pada pasien diabetes melitus tipe 2 (DMT2).

\section{METODE PENELITIAN}

Jenis penelitian ini ialah deskriptif analitik dengan menggunakan data sekunder dari rekam medik RSUP Prof. Dr. R. D. Kandou Manado. Penelitian dilakukan pada bulan September 2016 November 2016. Populasi penelitian ini mencakup seluruh pasien DMT2 baik lakilaki maupun perempuan di Poliklinik Endokrin Penyakit Dalam RSUP Prof. Dr. R. D. Kandou Manado. Sampel penelitian ini mencakup semua pasien DMT2 baik laki-laki maupun perempuan yang berobat di Poliklinik Endokrin Penyakit Dalam RSUP Prof. Dr. R. D. Kandou Manado selama bulan Agustus 2016-Oktober 2016. Variabel penelitian yaitu rerata gula darah, kadar hemoglobin, hematokrit, eritrosit, tombosit dan leukosit.

\section{HASIL PENELITIAN}

Penelitian ini dilaksanakan di Poliklinik Endokrin Bagian/SMF Ilmu Penyakit Dalam RSUP Prof. Dr. R. D. Kandou Manado. Pengambilan data 
penelitian ini dari bulan SeptemberNovember 2016. Pada penelitian ini didapatkan sampel penderita DMT2 yang memenuhi kriteria inklusi berjumlah 56 pasien.

Berdasarkan Tabel 1 terlihat bahwa sampel penderita DMT2 yang memenuhi kriteria inklusi berjumlah 56 pasien yang terbagi atas 18 pasien laki-laki dan 38 pasien perempuan.

Tabel 1. Distribusi pasien menurut jenis kelamin

\begin{tabular}{cc}
\hline Jenis kelamin & Jumlah \\
\hline Laki-laki & 18 \\
Perempuan & 38 \\
\hline
\end{tabular}

Berdasarkan Tabel 2 terlihat bahwa sampel penderita DMT2 terbanyak pada rentang umur $>45$ tahun dengan jumlah 45 pasien dan $\leq 45$ tahun sebanyak 9 pasien.

Tabel 2. Distribusi pasien menurut umur

\begin{tabular}{cc}
\hline Umur (tahun) & Jumlah \\
\hline$\leq 45$ & 9 \\
$>45$ & 45 \\
\hline
\end{tabular}

Berdasarkan Tabel 3 terlihat bahwa pada pasien laki-laki rerata kadar hemoglobin ialah 14,63 g/dL dan pada pasien perempuan 13,20 g/dL.

Tabel 3. Rerata kadar hemoglobin pasien DM tipe 2

\begin{tabular}{cc}
\hline Jenis kelamin & $\begin{array}{c}\text { Kadar hemoglobin } \\
\text { rerata }(\mathbf{g} / \mathbf{d L})\end{array}$ \\
\hline Laki-laki & 14,63 \\
Perempuan & 13,20 \\
\hline
\end{tabular}

Berdasarkan Tabel 4 terlihat bahwa pada pasien laki-laki rerata kadar hematokrit ialah $42,46 \%$ dan pada pasien perempuan $38,52 \%$.

Tabel 4. Rata-rata kadar hematokrit pasien DM tipe 2

\begin{tabular}{cc}
\hline Jenis kelamin & $\begin{array}{c}\text { Rerata kadar } \\
\text { hematokrit }\end{array}$ \\
\hline Laki-laki & 42,46 \\
Perempuan & 38,52 \\
\hline
\end{tabular}

Berdasarkan Tabel 5 terlihat bahwa pada pasien laki-laki rerata kadar eritrosit ialah 4,84 juta $\mu \mathrm{L}$ dan pada pasien perempuan 4,47 juta $\mu \mathrm{L}$.

Tabel 5. Rerata kadar eritrosit pasien DM tipe 2

\begin{tabular}{cc}
\hline Jenis kelamin & $\begin{array}{c}\text { Rerata } \\
\text { kadar eritrosit }\end{array}$ \\
\hline Laki-laki & 4,84 \\
Perempuan & 4,47 \\
\hline
\end{tabular}

Berdasarkan Tabel 6 dapat dilihat terdapat 52 pasien yang memiliki kadar trombosit normal. Rerata kadar trombosit normal pada pasien ialah $286,0 \times 10^{3} / \mathrm{mm}^{3}$ dengan nilai tertinggi $418 \times 10^{3} / \mathrm{mm}^{3}$ dan nilai terendah $195 \times 10^{3} / \mathrm{mm}^{3}$. Pasien yang mengalami trombositosis dan trombositopenia masing-masing sebanyak 2 pasien.

Berdasarkan Tabel 7 dapat dilihat terdapat 41 pasien yang memiliki kadar leukosit normal. Rerata kadar leukosit normal pada pasien ialah $7549,4 / \mathrm{mm}^{3}$ dengan nilai tertinggi $10000 / \mathrm{mm}^{3}$ dan nilai terendah $4560 / \mathrm{mm}^{3}$. Pasien yang mengalami leukositosis sebanyak 15 pasien; tidak ada pasien yang mengalami leukopenia.

Tabel 6. Distribusi sampel berdasarkan kadar trombosit

\begin{tabular}{|c|c|c|c|c|}
\hline Kadar trombosit & Jumlah & $\begin{array}{c}\text { Rerata } \\
\times 10^{3} / \mathbf{m m}^{3} \\
\end{array}$ & $\begin{array}{c}\text { Nilai tertinggi } \\
\times 10^{3} / \mathrm{mm}^{3}\end{array}$ & $\begin{array}{c}\text { Nilai terendah } \\
\times 10^{3} / \mathrm{mm}^{3}\end{array}$ \\
\hline Trombositopenia & 2 & 139,5 & 143 & 136 \\
\hline Normal & 52 & 286,0 & 418 & 195 \\
\hline Trombositosis & 2 & 609,5 & 686 & 533 \\
\hline
\end{tabular}


Kekenusa, Pandelaki, Haroen: Gambaran hematologi rutin...

Tabel 7. Distribusi sampel berdasarkan kadar leukosit

\begin{tabular}{|c|c|c|c|c|}
\hline Kadar leukosit & Jumlah & $\begin{array}{l}\text { Rerata } \\
/ \mathbf{m m}^{3}\end{array}$ & $\begin{array}{l}\text { Nilai tertinggi } \\
\qquad / \mathrm{mm}^{3}\end{array}$ & $\begin{array}{l}\text { Nilai terendah } \\
\qquad / \mathrm{mm}^{3}\end{array}$ \\
\hline Leukopenia & 0 & - & - & - \\
\hline Normal & 41 & 7549,4 & 10000 & 4560 \\
\hline Leukositosis & 15 & 12278,7 & 23300 & 10040 \\
\hline
\end{tabular}

Tabel 8. Hasil Analisis Korelasi Spearman Variabel Penelitian

\begin{tabular}{llll}
\hline \multicolumn{1}{c}{$\begin{array}{c}\text { Variabel } \\
\text { independen }\end{array}$} & \multicolumn{3}{c}{$\begin{array}{c}\text { Variabel dependen } \\
\text { Rerata Gula Darah } \\
(\mathbf{m g} / \mathbf{d L})\end{array}$} \\
& $\mathbf{r}$ & $\mathbf{p}$ & Ket \\
\hline $\begin{array}{l}\text { Hemoglobin } \\
(\mathrm{g} / \mathrm{dL})\end{array}$ & 0,083 & 0,272 & $\mathrm{~TB}$ \\
$\begin{array}{l}\text { Hematokrit } \\
(\%)\end{array}$ & 0,123 & 0,184 & $\mathrm{~TB}$ \\
$\begin{array}{l}\text { Eritrosit } \\
(1000000 / \mu \mathrm{L})\end{array}$ & 0,121 & 0,187 & $\mathrm{~TB}$ \\
$\begin{array}{l}\text { Trombosit } \\
(1000 / \mu \mathrm{L})\end{array}$ & $-0,052$ & 0,353 & $\mathrm{~TB}$ \\
$\begin{array}{l}\text { Leukosit } \\
(1000 / \mu \mathrm{L})\end{array}$ & 0,247 & $0,033^{*}$ & $\mathrm{~B}$ \\
\hline \begin{tabular}{l} 
Keterangan: TB (Tidak Bermakna) \\
\multicolumn{3}{c}{$\mathrm{B}$ (Bermakna) }
\end{tabular}
\end{tabular}

\section{BAHASAN}

Pada penelitian yang dilakukan di Poliklinik Endokrin Bagian Ilmu Penyakit Dalam RSUP Prof. Dr. R. D. Kandou Manado, didapati sebanyak 56 pasien yang menderita DM tipe 2 dan lebih banyak diderita oleh pasien perempuan yaitu sebanyak 38 orang dibanding pasien lakilaki yaitu 18 orang. Hal ini sejalan dengan penelitian yang dilakukan oleh Awad ${ }^{4}$ terhadap pasien DM tipe 2 sebanyak 138 pasien yang terdiri dari 60 laki-laki dan 78 perempuan.

Berdasarkan usia terlihat bahwa pasien DM tipe 2 terbanyak pada rentang usia > 45 tahun dengan jumlah 45 pasien dan $\leq 45$ tahun sebanyak 9 pasien. Hasil penelitian ini juga sejalan dengan data RISKESDAS 2007 yang mengemukakan bahwa, prevalensi DM di Indonesia pada penduduk usia $>15$ tahun meningkat dari 1,5-2,3\%. Hasil studi epidemiologi tentang DM di Manado juga menunjukkan angka yang lebih tinggi yaitu $6,1 \%{ }^{3}$ Hal ini juga sesuai dengan pernyataan Wild et al. ${ }^{12}$ bahwa prevalensi tertinggi diabetes di dunia berada pada usia >45 tahun, dan diperkirakan angkanya akan mengalami peningkatan dua kali lipat pada tahun 2030.

Berdasarkan hasil penelitian rerata kadar hemoglobin 14,63 g/dL pada lakilaki dan 13,20 g/dL pada perempuan. Pasien DMT2 yang memiliki rata-rata kadar hematokrit $42,46 \%$ pada laki-laki dan $38,52 \%$ pada perempuan. Pasien DMT2 yang memiliki rata-rata kadar eritrosit adalah 4,84 juta $\mu \mathrm{L}$ pada laki-laki dan 4,47 juta $\mu \mathrm{L}$ pada perempuan. Sampel penelitian yang diambil merupakan pasien DMT2 tanpa komplikasi.Hampir seluruh hasil masih menunjukkan dalam rentang normal baik laki-laki maupun perempuan. Ratarata normal kadar hemoglobin, hematocrit dan eritrosit berbeda menurut jenis kelamin. $^{13,14}$

Beberapa pasien yang didapati terjadi penurunan kadar hemoglobin, hematokrit dan eritrosit mungkin terjadi anemia ringan. Anemia pada pasien DMT2 tidak terkait secara langsung, tetapi komplikasi diabetes dan kondisi penyakit tertentu terkait dengan munculnya anemia. Diabetes belum tentu memunculkan anemia, tetapi DMT2 yang dapat mengembangkan resiko anemia.

Berdasarkan hasil penelitian dilihat terdapat 52 pasien yang memiliki kadar trombosit normal. Rerata kadar trombosit normal pada pasien ialah $286,0 \times 10^{3} / \mathrm{mm}^{3}$. Hampir seluruh pasien memiliki kadar trombosit normal itu karena pada penelitian ini diambil sampel pasien DMT2 yang belum disertai dengan komplikasi. Penelitian yang dilakukan oleh Erem ${ }^{15}$ mendapatkan adanya peningkatan jumlah trombosit pada pasien DMT2 dibandingkan dengan kontrol. Didapatkan bahwa jumlah trombosit lebih tinggi pada pasien DMT2 
dengan komplikasi vaskular retinopati dan nefropati dibandingkan dengan yang tanpa komplikasi. Pasien yang mengalami trombositosis dan trombositopenia masingmasing sebanyak 2 pasien. Hal ini tidak sejalan dengan penelitian yang dilakukan oleh Madan ${ }^{16}$ yang menemukan adanya penurunan jumlah trombosit pada pasien DMT2 tapi masih dalam rentang normal. Sampel penelitian yang diambil yaitu pasien DMT2 dengan komplikasi mikrovaskular. Juga ditemukan jumlah trombosit tidak berbeda secara bermakna antara pasien dengan komplikasi vaskular dan pasien tanpa komplikasi.

Berdasarkan hasil penelitian dilihat terdapat 41 pasien yang memiliki kadar leukosit normal. Rerata kadar leukosit normal pada pasien adalah $7549,4 / \mathrm{mm}^{3}$. Hampir seluruh pasien memiliki kadar leukosit normal itu karena pada penelitian ini diambil sampel pasien DMT2 DM yang belum disertai dengan komplikasi Pasien DMT2 tanpa komplikasi akan memberi hasil pemeriksaan darah dalam batas normal. Pasien yang mengalami leukositosis sebanyak 15 pasien dan tidak ada pasien yang mengalami leukopenia. Jumlah leukosit dipengaruhi oleh umur, penyimpangan dari keadaan basal dan lainlain. ${ }^{14}$

Berdasarkan hasil uji analisis bivariat melalui analisis korelasi Spearman, terdapat hubungan bermakna antara leukosit dan rerata gula darah. Berdasarkan hasil penelitian juga ditemukan tidak ada hubungan bermakna antara rerata gula darah dengan hemoglobin, hematokrit, eritrosit dan trombosit. Penelitian ini merupakan penelitian awal, oleh karena itu masih belum ada bukti lain atau penelitian sebelumnya untuk dibuat sebagai acuan dan perbandingan. Selanjutnya, perlu dilakukan penelitian bagaimana hubungan antara kadar leukosit dan rata-rata gula darah pada pasien DMT2.

\section{SIMPULAN}

Dari hasil penelitian pada pasien diabetes melitus tipe 2 dapat disimpulkan bahwa tidak terdapat hubungan bermakna antara nilai hemoglobin, hematokrit, eritrosit, dan trombosit dengan rerata kadar gula darah namun terdapat hubungan bermakna antara leukosit dengan rerata gula darah.

\section{DAFTAR PUSTAKA}

1. Rani AA, Soegondo S, Nazir AUZ, Wijaya IP, Nafrialdi, Mansjoer A. Panduan Pelayanan Medis (3rd ed). Jakarta: Interna Publishing, 2009; p. 9.

2. Fatimah NR. Diabetes Melitus Tipe 2. J Majority. 2015;4:94.

3. RISKESDAS. Jakarta: Litbangkes, 2013.

4. Awad N. Gambaran faktor resiko pasien diabetes melitus tipe II di Poliklinik Endokrin Bagian/SMF FK-Unsrat RSUP Prof. Dr. R. D. Kandou Manado periode Mei-Oktober 2011. eBm. 2013;1(1):47-8.

5. Kementrian Kesehatan Republik Indonesia. Tahun 2030 Prevalensi Diabetes Melitus di Indonesia Mencapai 21,3 Juta Orang. [cited 28 Agustus 2016]. Available from: http://www.depkes.go.id/article/view/4 14/tahun-2030-prevalensi-diabetesmelitus-di-Indonesia-mencapai-213juta-orang.html

6. Ferreiro JL, Angiolilo DJ. Diabetes and antiplatelet therapy in acute coronary syndrome. Circulation. 2011;123: 798813.

7. Capodanno D, Patel A, Dharmashankar K, Ferreiro JL, Ueno M, Kodali M, et al. Pharmacodynamic effects of different aspirin dosing regimen in type 2 diabetes mellitus patients with coronary artery disease. Circ Cardiovasc Interv. 2011;4:180-7.

8. Yngen M. Platelet hyperactivity in diabetes mellitus. Eur J Cardiol. 2005;1-4.

9. Kraw M. Antiplatelet therapy in diabetes. Endocrinology. 2002;2118-21

10. Piccin A, Murphy WG, Smith OP. Circulating microparticles: Pathophysiology and clinical implicatios. J Blood Review. 2007;21.

11. Music M, Fajkic A, Lepara O, Brankovic M, Abazovic AM, Allc A. Analysis of inflammatory parameter in diabetes mellitus type 2 patients with or without metabolic syndrome. Mater Sociomed. 2010;22(2):64-7.

12. Wild S, Roglic G, Green A, Sicree R, 
King H, et al. Global prevalence of diabetes: estimates for the year 2000 and projections for 2030. Diabet care. 2004;27(1):1047-53.

13. Bustan MN. Epidemiologi Penyakit Tidak Menular. Jakarta: PT Rineka Cipta, 2007; p. 101.

14. Perkumpulan Endokrinologi Indonesia. Konsensus pengelolaan dan pencegahan diabetes mellitus tipe 2 di
Indonesia. PB. PERKENI, 2011.

15. Guyton AC, Hall JE. Buku Ajar Fisiologi Kedokteran (12th ed). Jakarta: EGC, 2015.

16. Madan R, Grupta B, Sawja S, Konra UC, Triapthi BIC, Guliani BP. Coagulation profile in diabetes and its association with diabetic microvascular complications. JAPI. 2009;58:2181-84. 